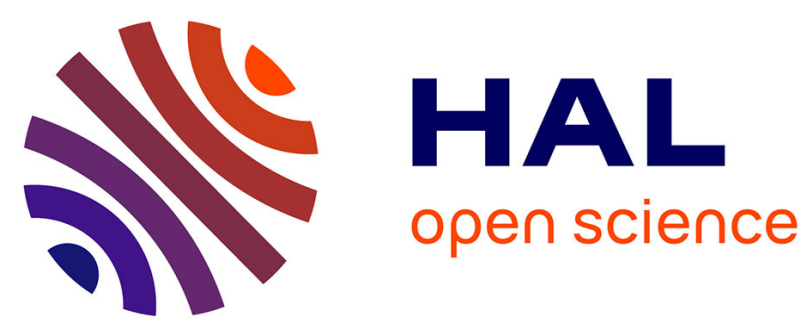

\title{
Pasteurization of citrus juices with ohmic heating to preserve the carotenoid profile
}

\author{
Nawel Achir, Claudie Dhuique-Mayer, Thiziri Hadjal, Khodir Madani, \\ Jean-Pierre Pain, Manuel Dornier
}

\section{To cite this version:}

Nawel Achir, Claudie Dhuique-Mayer, Thiziri Hadjal, Khodir Madani, Jean-Pierre Pain, et al.. Pasteurization of citrus juices with ohmic heating to preserve the carotenoid profile. Innovative Food Science \& Emerging Technologies / Innovative Food Science and Emerging Technologies , 2016, 33, pp.397-404. 10.1016/j.ifset.2015.11.002 . hal-01540843

\section{HAL Id: hal-01540843 \\ https://hal.science/hal-01540843}

Submitted on 16 Jun 2017

HAL is a multi-disciplinary open access archive for the deposit and dissemination of scientific research documents, whether they are published or not. The documents may come from teaching and research institutions in France or abroad, or from public or private research centers.
L'archive ouverte pluridisciplinaire HAL, est destinée au dépôt et à la diffusion de documents scientifiques de niveau recherche, publiés ou non, émanant des établissements d'enseignement et de recherche français ou étrangers, des laboratoires publics ou privés.

\section{(ㅇ)(1) $\$$}

Distributed under a Creative Commons Attribution - NonCommercial - NoDerivatives| 4.0 


\section{Accepted Manuscript}

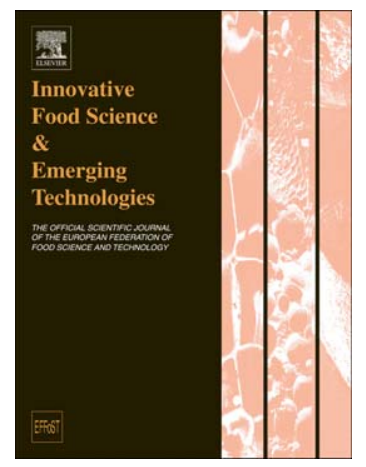

Pasteurization of citrus juices with ohmic heating to preserve the carotenoid profile

Nawel Achir, Claudie Dhuique-Mayer, Thiziri Hadjal, Khodir Madani, Jean-Pierre Pain, Manuel Dornier

PII:

S1466-8564(15)00215-5

DOI:

doi: $10.1016 /$ j.ifset.2015.11.002

Reference:

INNFOO 1399

To appear in: $\quad$ Innovative Food Science and Emerging Technologies

Received date: 21 May 2015

Revised date: $\quad 22$ October 2015

Accepted date: 5 November 2015

Please cite this article as: Achir, N., Dhuique-Mayer, C., Hadjal, T., Madani, K., Pain, J.-P. \& Dornier, M., Pasteurization of citrus juices with ohmic heating to preserve the carotenoid profile, Innovative Food Science and Emerging Technologies (2015), doi: 10.1016/j.ifset.2015.11.002

This is a PDF file of an unedited manuscript that has been accepted for publication. As a service to our customers we are providing this early version of the manuscript. The manuscript will undergo copyediting, typesetting, and review of the resulting proof before it is published in its final form. Please note that during the production process errors may be discovered which could affect the content, and all legal disclaimers that apply to the journal pertain. 
Pasteurization of citrus juices with ohmic heating to preserve the carotenoid profile

Nawel Achir ${ }^{1}$, Claudie Dhuique-Mayer ${ }^{2 *}$, Thiziri Hadjal ${ }^{2,3}$, Khodir Madani $^{3}$, Jean-Pierre Pain $^{4}$, Manuel Dornier ${ }^{1}$

${ }^{1}$ Montpellier SupAgro, UMR95 QualiSud, 1101 av. Agropolis, B.P. 5098, F-34093 Montpellier cedex 5, France

${ }^{1}$ CIRAD, UMR95 QualiSud, 73 av. J.F Breton, TA B-95/16, F-34398 Montpellier cedex 5, France

${ }^{3}$ Laboratoire de Biomathématique, Biophysique, Biochimie, et Scientométrie, Faculté des Sciences de la Nature et de la Vie, Université de Bejaia, 06000 Bejaia, Algeria.

${ }^{4}$ Université de Montpellier, UMR95 QualiSud, CC 023, Place Eugène Bataillon, F-34090 Montpellier, France

*Corresponding author: claudie.dhuique-mayer@cirad.fr

Dr. Claudie DHUIQUE-MAYER (HDR)

CIRAD

Département Systèmes de Production et Transformation

UMR Qualisud

TA B-95/16

73, Av.J.François Breton

34398 Montpellier cedex 5

Tel : (33) 04-67-61-44-82

Fax : (33) 04-67-61-44-33 
Abstract: This study was carried out to assess, for the first time, the effect of ohmic heating on the carotenoid profile of two citrus fruit juices: grapefruit and blood orange. Two heat treatments were designed to obtain pasteurization values of 50 and $150 \mathrm{~min}\left(\mathrm{Tref}=70^{\circ} \mathrm{C}\right.$ and $\mathrm{z}$-value $=10^{\circ} \mathrm{C}$ ) with ohmic heating as compared to conventional heating. The results showed that xanthophyll losses could reach $70 \%$ for epoxyxanthophylls (cis-violaxanthin and cis-antheraxanthin) and $40 \%$ for hydroxyxanthophylls ( $\beta$-cryptoxanthin, lutein, and zeaxanthin) with conventional heating, but losses were under $30 \%$ and $20 \%$, respectively, with ohmic heating. Carotene species (lycopene and $\beta$-carotene) were stable regardless of the treatment. No negative nonthermal effects of ohmic heating were shown on carotenoids. Loss simulations of the studied carotenoids showed that the high temperatures reached with ohmic heating during pasteurization could substantially increase the organoleptic and nutritional quality of acid carotenoid-rich juices.

Key words : Citrus juices; ohmic heating; pasteurization; kinetics; modelling; carotenoids 


\section{Introduction}

Citrus fruits are grown in over 100 countries under tropical, subtropical and Mediterranean climates. They represent the top fruit crop in terms of world trade value (Khan \& Kender, 2007). Citrus fruits have a high phytochemical content, including ascorbic acid, carotenoids and polyphenols (Dhuique-Mayer, Caris-Veyrat, Ollitrault, Curk, \& Amiot, 2005; Ladanyia, 2008). Carotenoids are classified into two categories according to their structure: carotenes, non-polar hydrocarbons, and xanthophylls, which contain for the main either hydroxyl, epoxide, or keto functions in the end group (Britton, Liaanen-Jensen, \& Pfander, 2004) (Fig. 1). These compounds are classified among food-bound exogenic antioxidants that are essential for counteracting oxidative stress. (Laguerre, Lecomte, \& Villeneuve, 2007). Among citrus juices, sweet orange juice (Citrus sinensis) present the most complex carotenoid profile with a large type of xanthophyll. The main forms are esterified cis-violaxanthin, $\beta$ cryptoxanthin, lutein, zeaxanthin and cis-antheraxanthin (Dhuique-Mayer, et al., 2005). Conversely, grapefruit juice (Citrus paradisi) has a simple carotenoid profile with two carotenes, i.e. lycopene and $\beta$-carotene (Fanciullino, Dhuique-Mayer, Luro, Casanova, Morillon, \& Ollitrault, 2006; Xu, Tao, Liu, \& Deng, 2006).

Among the 10.9 million $t$ of citrus products traded in 2009, sweet orange accounted for approximately $60 \%$ of citrus production in terms of both fresh fruit and processed juice consumption (FAOstat, 2015). Approximately $40 \%$ of all citrus produced worldwide is processed, with sweet orange and grapefruit juices representing major volumes (Johnson, 2000). Juice processing involves a stabilization step that boosts the shelf-life from 1 to 3 weeks for fresh fruits, and up to 18 months for pasteurized juices. Pasteurization is a heat treatment process that inactivates natural endogenous enzymes (pectin methylesterase, peroxidase, etc.) and microorganisms via heating at temperatures below $100^{\circ} \mathrm{C}$ (Demirdoven 
\& Baysal, 2014). This treatment, associated with the acidity of citrus juice $(\mathrm{pH}<4)$, inhibits the development of heat-resistant pathogenic flora and enables storage at room temperature in aseptic hermetically sealed packaging.

Juice heat treatments are associated with quality depletion because of vitamin destruction and flavor component damage. Carotenoids, for instance, are sensitive to light, temperature and chemical exposure (metals, oxygen) during processing (Amaya, 2001). As heat can alter the nutritional and organoleptic properties, improvements in process technologies are sought to minimize juice heat exposure. This issue meets consumer demand for improved flavor and less-processed products (closer to fresh juice). Minimal processed juices now have a significant market share (Johnson, 2000).

Pasteurization is conventionally achieved by heat exchange, whereby heat is transferred by conduction from steam or hot water to the product. The heat exchange is more or less efficient depending on the pasteurizer design and technological choices. Ohmic heating ensures better thermal efficiency, so this technique is currently gaining ground and several continuous plants are now using it in the food industry (Butz \& Tauscher, 2002; Demirdoven, et al., 2014). Ohmic heating devices are equipped with electrodes that enable the passage of alternating electrical current through the food product, thus generating internal heat as the result of electrical resistance, which is known as the Joule effect. Instant high volume heating occurs and gives a uniform temperature distribution, especially for liquid foods with high electrical conductivity (Demirdoven, et al., 2014; Goullieux \& Pain, 2014; Icier, Yildiz, \& Baysal, 2008; Jakób, Bryjak, Wójtowicz, Illeová, Annus, \& Polakovic, 2010).

This technology reduces thermal damage to food for many reasons. Indeed, heating and cooling are immediate (Sakr \& Liu, 2014). This avoids over-processing of the food product, while achieving higher temperatures. Indeed, high temperature/short-term treatments are known to be efficient in destroying enzymes and bacteria while preserving the nutritional and 
organoleptic qualities. This could be explained by the fact that the temperature dependency is higher for microorganism destruction than for nutrient degradation, as illustrated in Table 1, where the z-values are generally under $10^{\circ} \mathrm{C}$ for microorganisms and enzymes while being above $20^{\circ} \mathrm{C}$ for compounds of organoleptic or nutritional interest. Fruit products processed using ohmic technologies have thus been found to have a better organoleptic properties (Leizerson \& Shimoni, 2005a, 2005b; Pataro, Donsi, \& Ferrari, 2011).

Non-thermal effects due to electrical fields represent a further feature of ohmic treatment efficiency (Butz, et al., 2002). Indeed, as shown in Table 1, activation energies are higher for pectin methyl esterase inactivation but also for ascorbic acid degradation during ohmic heating in comparison to conventional heating. In addition, (Somavat, Mohamed, \& Sastry, 2013) showed that degradation was faster for Bacillus coagulans in case of ohmic treatment (lower D-values). Electrical fields did not affect vitamin $\mathrm{C}$ degradation in acerola juices or orange juices (Mercali, Schwartz, Marczak, Tessaro, \& Sastry, 2014; Vikram, Ramesh, \& Prapulla, 2005). However, at high voltage, (Sarkis, Jaeschke, Tessaro, \& Marczak, 2013) showed that the level of anthocyanins degradation was greater during ohmic-heating of blueberry pulp in comparison to conventional heating. To the best of our knowledge, no studies have been conducted on the effect of such technology on carotenoids. Vikram et al. (2005) only studied variations in orange juice colour using a chromameter, but no HPLC carotenoid quantification was done (Vikram, et al., 2005).

Our study was thus carried out with the aim of studying carotenoid degradation in blood orange and grapefruit juices during conventional heating, i.e. by convection-diffusion, and ohmic heating. The carotenoids monitored were both xanthophylls and carotenes, which encompass the main structural diversity of this molecular family. In addition, previously published degradation parameters obtained on the same citrus juices matrices were used to 
represent their behavior during thermal processing. The findings of this study could therefore contribute to the lack of information about nutrient behavior during ohmic heating. 
Table 1. Heat sensitivity parameters (activation energy and z-value) of enzymes and microorganism destruction and nutrient degradation in different fruit juices during conventional and ohmic heating

\begin{tabular}{|c|c|c|c|c|c|c|c|c|}
\hline \multirow{3}{*}{$\begin{array}{l}\text { Compound } \\
\text { Pectin methyl } \\
\text { esterase }\end{array}$} & \multirow{3}{*}{$\begin{array}{l}\text { Fruit juices } \\
\text { Apple juice }\end{array}$} & \multirow{2}{*}{\multicolumn{2}{|c|}{$\begin{array}{c}\text { Temperature range } \\
\left({ }^{\circ} \mathrm{C}\right)\end{array}$}} & \multicolumn{2}{|c|}{$\begin{array}{l}\text { Conventional } \\
\text { heating }\end{array}$} & \multicolumn{2}{|c|}{ Ohmic heating } & \multirow[b]{2}{*}{ Reference } \\
\hline & & & & $\begin{array}{l}\mathrm{Ea}(\mathrm{kJ} \\
\left.\mathrm{mol}^{-1}\right)\end{array}$ & $\begin{array}{c}\mathrm{Z} \\
\left({ }^{\circ} \mathrm{C}\right)\end{array}$ & $\begin{array}{c}\mathrm{Ea}(\mathrm{kJ} \\
\left.\mathrm{mol}^{-1}\right)\end{array}$ & $\left({ }^{\circ} \mathrm{C}\right)$ & \\
\hline & & 54 & 66 & 309 & & 328 & 6 & (Jakób, et al., 2010) \\
\hline $\begin{array}{l}\text { Bacillus } \\
\text { coagulans }\end{array}$ & Tomato juice & 95 & 110 & & 9 & 238 & 10 & (Somavat, et al., 2013) \\
\hline Ascorbic acid & Orange juice & 50 & 90 & 40 & 49 & 47 & 42 & (Vikram, et al., 2005) \\
\hline$\beta$-carotene & Citrus juice & 75 & 100 & $J_{110}$ & 20 & & & $\begin{array}{l}\text { (Dhuique-Mayer, Tbatou, Carail, Caris-Veyrat, Dornier, \& Amiot, } \\
\text { 2007) }\end{array}$ \\
\hline Anthocyanins & Acerola juice & 75 & 90 & 75 & 28 & 75 & 28 & (Mercali, Jaeschke, Tessaro, \& Marczak, 2013) \\
\hline
\end{tabular}




\section{Material and methods}

\subsection{Juices}

Sanguinelli variety blood oranges (Citrus sinensis L. Osbeck) were from the Benyoub agricultural field (Bejaia, Algeria) and South American pink grapefruits (Citrus paradisi Macf) were purshased in a market. The fruits were cut in half and pressed using a domestic juicer (Moulinex Masterchef 470, France). The juice was filtered through a stainless steel sieve $(1 \mathrm{~mm})$. The freshly pressed juice was placed in amber glass bottles, and stored under nitrogen at $-20^{\circ} \mathrm{C}$ prior to analysis or heat treatment.

\subsection{Heating devices}

For conventional heating, $4 \mathrm{~mL}$ of juice were placed in $10 \mathrm{~mL}$ sealed glass tubes. Three tubes per test were immersed in an oil bath under temperature control (Memmert, Legallais, France). With this small juice volume, the temperature was homogeneous throughout the tube. A digital temperature probe (EKT 3001, Heidolph, Germany) fitted to a reference tube was used to measure the juice temperature during the thermal experiments. After thermal treatment, the three tubes were rapidly cooled in an ice bath.

Ohmic treatments were performed in a $100 \mathrm{~mL}$ capacity laboratory-scale static reactor, as described in (Roux, Courel, Picart-Palmade, \& Pain, 2010). Electrodes were made of titanium covered with a specific alloy to avoid electrolysis. A $5 \mathrm{~kW}$ power supply delivering a $50 \mathrm{~Hz}$ alternative current and generating a steady electric field from 0.1 to 3 $\mathrm{kV} \cdot \mathrm{m}^{-1}$ was used for heating. A take-away sampling system allowed sampling of three volumes of $4 \mathrm{~mL}$ each per batch. The extracted samples were also rapidly cooled in an ice bath. The bulk temperature was continuously monitored with a type $\mathrm{K}(\mathrm{NiCr} / \mathrm{NiAl})$ 
thermocouple (diameter $1.5 \mathrm{~mm}$, precision $\pm 1.5^{\circ} \mathrm{C}$ ) positioned at the bottom of the cell. The calibration of the thermocouple was checked with boiling water. The temperature signal was compared with and without application of the electrical field and no deviation was found regarding the sensor. This sensor controlled the monitoring equipment (Simulator Control And Data Acquisition -

SCADA) which, via a LabVIEW ${ }^{\circledR}$ program, acted on the voltage applied between the electrodes in order to regulate the holding temperature at a targeted value (proportional-integral controller). During the holding stage, the temperature was thus maintained at a constant level by providing enough power to compensate for the energy lost at the cell walls. The process control system enabled the accurate management of time/temperature conditions and on-line data collection (voltage \pm $0.25 \%$, current $\pm 0.5 \%$ and a maximum of five temperatures with a minimum delay of $0.2 \mathrm{~s}$ )

\subsection{Pasteurization value calculation}


Usual industrial target pasteurization values were chosen: 50 and $150 \mathrm{~min}$ at $70^{\circ} \mathrm{C}$ using $\mathrm{z}$ value of $10^{\circ} \mathrm{C}$. These pasteurization values are in accordance with that proposed by Tucker (2011) (Tucker \& Featherstone, 2011). A z-value of $10^{\circ} \mathrm{C}$ was chosen because it is in the range of $8-11^{\circ} \mathrm{C}$-values of spoilage micro-organisms in high-acid fruit products (Silva \& Gibbs, 2004)

Pasteurization value $(\mathrm{P})$ is the equivalent time in $\min$ at $T_{\text {ref }}$ obtained from the timetemperature curve of a product during a heat process to evaluate a pasteurizing process according to eq (1):

$P=\int_{t_{0}}^{t_{\text {end }}} 10^{\left(\frac{T(t)-T_{r e f}}{z}\right)} \cdot d t$

eq. 1

Where $T$ is the temperature in ${ }^{\circ} \mathrm{C}$ at each time $t$ in min.

\subsection{Scale design}

Tests were previously carried out to assess the duration of each thermal treatment step (heating, holding and cooling stages) in each configuration (conventional and ohmic heating) so as to determine the relevant scale for the four different treatments:

- Treatments 1 and 2: Conventional heating with P-value of 50 and $150 \mathrm{~min}$

- Treatments 3 and 4: Ohmic heating with P-value of 50 and 150 min

For conventional heating, the set temperature was the maximum temperature reached in the juice for P-value of $50 \mathrm{~min}$, i.e. $80^{\circ} \mathrm{C}$. For ohmic heating, the set temperature was $95^{\circ} \mathrm{C}$. 
Therefore, 4 scales were obtained. Treatments 1 and 3 were representative of high term-low temperature- treatments (convection/diffusion phenomena) while treatments 3 and 4 were short term-high temperature-treatments obtained thanks to ohmic heating.

\subsection{Kinetic modelling}

Carotenoid degradation is generally described via first-order kinetics (Penicaud, Achir, Dhuique-Mayer, Dornier, \& Bohuon, 2011). Carotenoid concentration variations are thus assumed to follow eq. 2 .

$$
\frac{d C}{d t}=-k C
$$

Where $\mathrm{C}$ represents the carotenoid concentration $\left(\mathrm{mg} \mathrm{L}^{-1}\right), t$ the time (min), and $k$ the reaction rate constant $\left(\mathrm{min}^{-1}\right)$.

The rate constants $k$ were assumed to vary with the temperature according to the Arrhenius law (eq. 3).

$$
k=k_{r e f} \exp \left(\frac{-E_{a}}{R}\left(\frac{1}{T}-\frac{1}{T_{r e f}}\right)\right)
$$

eq. 3

Where $k_{r e f}$ is the rate constant at the reference temperature $\left(70^{\circ} \mathrm{C}\right), E a, T$ and $R$, respectively, the activation energy $\left(\mathrm{J} \mathrm{mol}^{-1}\right)$, bulk temperature $(\mathrm{K})$ and gas constant $\left(8.314 \mathrm{~J} \mathrm{~mol}^{-1} \mathrm{~K}^{-1}\right)$.

As the temperature was not constant during the four heat processes, the concentrations of each carotenoid were obtained by integrating the following equation 4 using Matlab® software (The Mathworks Inc., USA):

$$
\frac{d[C]}{d t}=-k_{70^{\circ} \mathrm{C}} \cdot \exp \left(\frac{E a}{R} \cdot\left(\frac{1}{70}-\frac{1}{T(t)}\right)\right) \cdot[C]
$$

$E a$, and $k_{r e f}$ were derived from previous published papers obtained in the same matrix, as presented in Fig. 2 (Achir, Hadjal, Madani, Dornier, \& Dhuique-Mayer, 2015; Hadjal, Dhuique-Mayer, Madani, Dornier, \& Achir, 2013). These constants were calculated from the 
experimental points presented in the papers with a one order kinetic model and a secondary Arrhenius model. The uncertainty of the optimized parameters obtained with the LevenbergMarquardt algorithm was calculated by non-linear error propagation using Matlab® software (The Mathworks Inc., USA).

Confidence intervals of the simulated concentrations (eq. 4) were obtained via the of bootstrapping simulation method. The principle is the generation of a high number (500) of resamples of the kinetic dataset added with a Gaussian perturbation within the experimental standard deviations (Fig. 2). These virtual data were generated via Matlab® software (The Mathworks, Inc., USA).

\subsection{Carotenoid extraction and analysis}

$4 \mathrm{~mL}$ of blood orange juice (or $2 \mathrm{~mL}$ of grapefruit juice) were extracted three times with $3 \mathrm{~mL}$ (or $2 \mathrm{~mL}$ ) of hexane. Before extraction, $20 \mu \mathrm{l}$ of internal standard ( $\beta$-carotene or $\beta$ apo8'carotenal) were added in order to estimate carotene loss during the manipulations. The mixture was shaked for $30 \mathrm{~s}$ and centrifuged for $7 \mathrm{~min}$ at $2400 \mathrm{~g}$. The hexane phase was then evaporated for 15 min (GeneVac® EZ-2 compatible, UK). Saponification was conducted for blood orange juice according to (Granado, Olmedilla, Gil-Martinez, \& Blanco, 2001) with slight modifications. Extracts were saponified by adding $1.5 \mathrm{~mL}$ of hexane and $1.5 \mathrm{~mL}$ of $10 \% \mathrm{KOH}$, placed under nitrogen and stirred for $4 \mathrm{~h}$ at room temperature in darkness. The carotenoid extract was then washed with $3 \times 1 \mathrm{ml}$ of distilled water. The aqueous phase was extracted twice with a hexane/dichlomethane (5/1 v/v) mixture. Organic phases were pooled and the solvent was evaporated with a vacuum-centrifuge system (GeneVac® EZ-2 compatible, UK).

Carotenoids were analyzed by reverse-phase HPLC using the Agilent ${ }^{\circ} 1100$ system (Massy, France) according to Dhuique-Mayer et al. (2007). They were separated using a C30 column 
(250 mm x $4.6 \mathrm{~mm}, 5 \mu \mathrm{m}$ YMC) (Europ $\mathrm{GmbH}$, Germany), and the mobile phase was $\mathrm{H}_{2} \mathrm{O}$ as eluent A, methanol as eluent B, methyl tert-butyl ether as eluent $\mathrm{C}$. The flow rate was set at 1 $\mathrm{mL} \min ^{-1}$ and the injection volume was $20 \mu \mathrm{L}$. A solvent gradient was programmed as follows: initial conditions $40 \%$ A-60\% B; 0-7 min, 20\% A-80\% B 7-10 min, 4\% A-81\% B15\% C 10-60 min, 4\% A-11\% B- 85\% C 60-71 min, 100\% B 71-72 min, with a return to the initial conditions for rebalancing. Xanthophylls were detected at $450 \mathrm{~nm}$ using an Agilent® photodiode array detector. Xanthophylls were quantified using the calibration curve of $\beta$ cryptoxanthin. $\beta$-carotene and lycopene and their isomers were detected at 450 and $470 \mathrm{~nm}$, respectively (Dhuique-Mayer, et al., 2007).

\subsection{Statistical analysis}

Each carotenoid analysis was repeated 4 times. Statistica ${ }^{\circledR}$ (StatSoft, Inc., USA) was used to perform analysis of variance on replicates.

\section{Results}

\subsection{Initial juice characterization}

The initial carotenoid contents in both juices are presented in Table 2. The five main xanthophylls identified were cis-violaxanthin, lutein, zeaxanthin, cis-antheraxanthin and $\beta$ cryptoxanthin, which have already been identified in Algerian blood oranges (Hadjal, et al., 2013). The total xanthophyll concentration from the presented blood orange juice was 12.2 $\mathrm{mg} \mathrm{L} \mathrm{L}^{-1}$. Among these xanthophylls, cis-violanxanthin, an epoxyxanthophyll (Fig. 1) represented about $50 \%$ and $\beta$-cryptoxanthin $20 \%$ of the total amount. The three others 
represented about $10 \%$ each. These results were in accordance with those reported by Guiffrida et al. (2010), who also found that the major xanthophylls, regardless of the blood orange variety, were cis-violaxanthin and $\beta$-cryptoxanhtin (Giuffrida, Dugo, Salvo, Saitta, \& Dugo, 2010). In grapefruit juice, lycopene was the major carotene and represented $80 \%$ of the total amount ( $\beta$-carotene represented the other $20 \%$ ). These results were in accordance with those of $\mathrm{Xu}$ et al. (2006), who found a lycopene/ $\beta$-carotene ratio of close to 3 in red grapefruit. The initial $\mathrm{pH}$ of juices were 3.8 and 3.0, and the electrical conductivity $(\sigma)$ was 0.36 and $0.35 \mathrm{~S} \mathrm{~m}^{-1}$ for orange juice and grapefruit, respectively. Therefore, the juice $\mathrm{pH}$ values were under 3.8, so they could be considered as acidic juices and the chosen thermal death time was suitable (see Materials and methods). Their conductivity was in the citrus juice range and was considered suitable for ohmic processes $\left(\sigma>0.05 \mathrm{~S} \mathrm{~m}^{-1}\right.$ ) (Goullieux, et al., 2014).

\subsection{Degradation of carotenoids after conventional and ohmic heating}

The juice bulk temperatures during heat treatments are presented in Fig. 3 A) for conventional heating and in Fig. 3 B) for ohmic heating. The temperature profiles differed markedly as a function of the heating device. Indeed, during conventional heating, the time to reach $80^{\circ} \mathrm{C}$, the set temperature, was $24 \mathrm{~min}$, while the time necessary to reach $95^{\circ} \mathrm{C}$ during ohmic heating was $0.8 \mathrm{~min}$. The average heating speed of $80^{\circ} \mathrm{C} \mathrm{min}^{-1}$ during ohmic heating was thus 160 fold superior to the $2^{\circ} \mathrm{C} \min ^{-1}$ obtained during conventional heating. The heating curves have different shapes. During conventional heating, the temperature curve followed a typical first order response to the oil bath temperature regulator, with the asymptote value being the set temperature. The long heating period was due to the high thermal inertia of the system. In contrast, heating was almost immediate during ohmic heating and the heating curve was an exponential function of the time. The corresponding pasteurization values as a function of the 
treatment time are presented for conventional and ohmic heating in Fig. $3 \mathrm{C}$ and $\mathrm{D}$, respectively, for final pasteurization values of 50 and $150 \mathrm{~min}$. Therefore, the overall treatment lasted 24 and $32 \mathrm{~min}$ for conventional heating and 0.95 and $1.33 \mathrm{~min}$ for ohmic heating for $\mathrm{PV}=50$ and $150 \mathrm{~min}$, respectively. For the lowest pasteurization value, the holding step at $80^{\circ} \mathrm{C}$ only lasted a few seconds because of the slow heating step and the high pasteurization value accumulated during this phase. Indeed, during the first $20 \mathrm{~min}$, i.e. $80 \%$ of the treatment time, $50 \%$ of the 50 min $\mathrm{P}$ value was reached. Therefore, for $\mathrm{PV}=50 \mathrm{~min}$ in the conventional device, most of the thermal treatment contribution occurred under $80^{\circ} \mathrm{C}$. This was clearly a long term-low temperature treatment. During ohmic heating, even for the lowest pasteurization value of $50 \mathrm{~min}, 95^{\circ} \mathrm{C}$ was achieved and there was a holding step. Therefore, the higher contribution to the pasteurization effect occurred during the high temperature holding step, as illustrated by the shape of the pasteurization curve which was close to zero during the heating step and markedly increased around the holding stage. Therefore, this was a short term-high temperature treatment and it was even more efficient than in high efficiency conventional heat exchangers.

The extent of carotenoid degradation during the four treatments is presented in Table 2 for conventional and ohmic heating for $\mathrm{P}=50$ and $150 \mathrm{~min}$ in orange and grapefruit juices. The statistical analysis showed no significant degradation for the two carotenes, i.e. lycopene and $\beta$-carotene, regardless of the thermal treatment. This was consistent with previously published findings which showed high carotene stability. Indeed, no degradation of lycopene and $\beta$ carotene was observed during a 120 min-process of tomato sauce production involving a holding time of $35 \mathrm{~min}$ at $96^{\circ} \mathrm{C}$ (Chanforan, Loonis, Mora, Caris-Veyrat, \& Dufour, 2012). Therefore, no significant carotenoid degradation was observed when grapefruit juice was treated. Conversely, significant degradation was observed for xanthophylls in blood orange 
juice during conventional heating. The lowest degradation values were noted for lutein and zeaxanthin, with losses of 15 and $30 \%$ for PV of 50 and $150 \mathrm{~min}$. Similar losses of 30 to $35 \%$ were obtained for $\beta$-cryptoxanthin in the same conditions. The highest losses were obtained for cis-violaxanthin and cis-antheraxanthin, with $45-70$ and $30-70 \%$, respectively. These results showed a clear relationship between reactivity and structure - among carotenoids, the reactivity increased with molecule oxygenation, and among oxygenated functions, molecules with an epoxide function were more reactive (to isomerization in the furanoxide function) than those with hydroxyl groups (Dhuique-Mayer 2007). These results thus showed that during long term-low temperature pasteurization treatments, xanthophyll degradation was non-negligible and could reach more than $50 \%$ for epoxycarotenoids, cis-violaxanthin and cis-antheraxanthin. To the best of our knowledge, these losses have not been measured during thermal treatment in any paper. Indeed, xanthophylls have been much less studied than carotene. This degradation may be associated with quality depletion and particularly color loss (Dhuique-Mayer, et al., 2007). However, no xanthophyll degradation was observed during ohmic heating, except at the highest pasteurization with 15 to $26 \%$ degradation for cisviolaxanthin, lutein and $\beta$-cryptoxanthin. Moderate ohmic heating thus enabled preservation of all carotenoids, including the epoxy carotenoids. Ohmic treatment proved here to have no non-thermal deleterious effects on carotenoids (carotene or xanthophylls) and gave the best retention of even the most sensitive molecules.

Table 2. Initial and final xanthophyll and carotene concentrations $\left(\mathrm{mg} \mathrm{L}^{-1}\right)$ in blood orange and grapefruit juices after conventional and ohmic heating at the two pasteurization values (50 and $150 \mathrm{~min}$ ).

\begin{tabular}{|l|c|c|c|c|c|c|c|}
\cline { 2 - 7 } \multicolumn{1}{c|}{} & \multicolumn{4}{c|}{ Orange juice } & \multicolumn{2}{c|}{ Grapefruit juice } \\
\cline { 2 - 7 } \multicolumn{1}{c|}{} & cis-violaxanthin & Lutein & Zeaxanthin & cis-antheraxanthin & $\beta$-cryptoxanthin & Lycopene & $\beta$-carotene \\
\hline Initial juice & $6.1(0.4)^{\mathrm{a}}$ & $1.3(0.1)^{\mathrm{a}}$ & $1.3(0.1)^{\mathrm{a}}$ & $1.4(0.1)^{\mathrm{a}}$ & $2.1(0.2)^{\mathrm{a}}$ & $13.7(0.6)^{\mathrm{a}}$ & $3.8(0.2)^{\mathrm{a}}$ \\
\hline
\end{tabular}




\begin{tabular}{|l|c|c|c|c|c|c|c|} 
Conventional P 50 & $3.5(0.2)^{\mathrm{b}}$ & $1.0(0.2)^{\mathrm{a}}$ & $1.1(0.2)^{\mathrm{ab}}$ & $1.0(0.2)^{\mathrm{ab}}$ & $1.5(0.1)^{\mathrm{b}}$ & $15.5(0.5)^{\mathrm{a}}$ & $4.1(0.1)^{\mathrm{a}}$ \\
\hline Conventional P 150 & $1.7(0.1)^{\mathrm{b}}$ & $0.8(0.1)^{\mathrm{b}}$ & $0.8(0.1)^{\mathrm{b}}$ & $0.4(0.1)^{\mathrm{b}}$ & $1.4(0.1)^{\mathrm{b}}$ & $14.1(0.2)^{\mathrm{a}}$ & $3.8(0.1)^{\mathrm{a}}$ \\
\hline Ohmic P 50 & $7.4(0.3)^{\mathrm{a}}$ & $1.2(0.1)^{\mathrm{a}}$ & $1.4(0.2)^{\mathrm{a}}$ & $1.4(0.1)^{\mathrm{a}}$ & $2.0(0.1)^{\mathrm{a}}$ & $13.4(0.7)^{\mathrm{a}}$ & $3.6(0.1)^{\mathrm{a}}$ \\
\hline Ohmic P 150 & $5.1(0.1)^{\mathrm{a}}$ & $1.0(0.2)^{\mathrm{a}}$ & $1.3(0.1)^{\mathrm{a}}$ & $1.3(0.4)^{\mathrm{a}}$ & $1.8(0.1)^{\mathrm{b}}$ & $13.5(0.4)^{\mathrm{a}}$ & $3.5(0.1)^{\mathrm{a}}$ \\
\hline
\end{tabular}

Values are means of three determinations with standard deviations in brackets. Values bearing different letters in the same column are significantly different $(\mathrm{p}<0.005)$.

\subsection{Simulation of carotenoid retention}

Simulated final concentrations were calculated from the kinetic values of Fig. 2. Carotenoid retentions $\left(\mathrm{C} / \mathrm{C}_{\mathrm{t}=0}\right)$ are compared for experimental and simulated concentrations in Fig. 4 for conventional heating (A and B for PV of 50 and $150 \mathrm{~min}$ ) and ohmic heating (C and D for Pvalue of 50 and $150 \mathrm{~min}$ ). Overall, the trends obtained for the simulated results were in accordance with those of the experimental results. Indeed, the highest simulated retentions (95 to $100 \%$ ) were obtained for ohmic heating and P-value 50 min and the lowest retentions (50 to $95 \%$ ) for the conventional treatment with $\mathrm{P}$-value $150 \mathrm{~min}$. Moreover, the highest retentions were obtained for carotenes (lycopene and $\beta$-carotene), then hydroxyl xanthophylls ( $\beta$-cryptoxanthin, lutein, zeaxanthin) and finally epoxy-xanthophylls (cis-violaxanthin and cis-antheraxanthin). For instance, for the conventional treatment with $\mathrm{P}$ - value150 min, simulated retentions for expoxy-xanthophylls were 50 and $60 \%$, compared to $30 \%$ obtained experimentally. Simulated retentions of hydroxy-xanthophylls were similar (80\%), compared to $60 \%$ obtained experimentally. Simulated retentions of carotene were above $95 \%$, similar to the experimental findings. The simulated results were slightly overestimated in comparison to the experimental points. These differences may be attributed to experimental error and kinetic parameter uncertainty. Indeed, parameters were themselves identified from experimental data presenting a relative uncertainty. The kinetic parameters in Fig. 2 show high variation as a function of the molecule structure. The reference rate constants were higher for epoxy- 
xanthophylls and lower for carotene, while the three hydroxyl-xanthophylls had intermediary values. Regarding the activation energies, the lowest were obtained for carotene and the highest for zeaxanthin and $\beta$-cryptoxanthin. A similar activation energy of $156 \mathrm{~kJ}^{\mathrm{mol}}{ }^{-1}$ was obtained for this latter molecule in Dhuique-Mayer, et al., (2007).

To represent the prediction error, $95 \%$ confidence intervals were calculated from the kinetic parameter uncertainty (Fig. 2). Confidence intervals were obtained by 500 initializations of kinetic data within their experimental error intervals. The results are presented in Fig. 5 for conventional and ohmic heating for a pasteurization value of $150 \mathrm{~min}$. Logically, the $95 \%$ confidence intervals were broader for conventional heating as the degradation was greater. The final reduced concentrations $\left(\mathrm{C} / \mathrm{C}_{\mathrm{t}=0}\right)$ ranged from 0.47 to 0.57 and from 0.59 to 0.63 for cis-violaxanthin and cis-antheraxanthin during conventional heating, while the range was narrower (0.95-0.97) for ohmic heating. Therefore, ohmic was a real added value regarding the retention of these molecules. Lutein also exhibited a better final reduced concentration (0.97-0.99) in ohmic heating in comparison to conventional heating (0.79-0.86). Because of their higher activation energies and higher uncertainty, the conclusions were less clearcut for zeaxanthin and $\beta$-cryptoxanthin, which exhibited final retentions ranging from $0.72-0.93$ and 0.77-0.96 during conventional heating, as compared to $0.83-1$ and $0.88-1$ during ohmic heating.

Fig. 6 shows heating times corresponding to $10 \%$ loss of carotenoids from 40 to $140^{\circ} \mathrm{C}$ and also the time necessary to reach a mean P-value of $100 \min \left(T_{r e f}=70^{\circ} \mathrm{C}, \mathrm{z}\right.$-value $\left.=10^{\circ} \mathrm{C}\right)$. This time is often chosen to reach a satisfactory sanitary quality for acidic fruit juices. This graph shows that all carotenoids exhibited at least $10 \%$ loss at treatment temperatures of less than $70^{\circ} \mathrm{C}$. Indeed, the time necessary to reach $10 \%$ loss was under $100 \mathrm{~min}$. Losses may be less than $10 \%$ for carotene at temperatures ranges above $70^{\circ} \mathrm{C}$. In the case of hydro- and 
epoxyxanthophylls, the treatment temperatures should be above $80^{\circ} \mathrm{C}$ and $85^{\circ} \mathrm{C}$, respectively, to limit their degradation. This graph confirms that the thermal treatment conditions had a substantial influence on the carorotenoid profile and thus on the organoleptic and nutritional qualities.

\section{Conclusion}

This study firstly showed that ohmic heating was suitable for products with a high carotenoid content. No non-thermal effects of ohmic heating were shown to be detrimental for these molecules. All typologies of common carotenoids were studied, including epoxyxanthophylls, hydroxy-xanthophylls and carotene. Pasteurization with ohmic heating proved to be a very good alternative for protecting epoxy-xanthophylls, which were strongly degraded during conventional heating. Other xanthophylls were also significantly more preserved during ohmic treatment. Besides the antioxidant advantages of preserving all carotenoids, in future studies these encouraging results could be accompanied by sensory analyses to study organoleptic improvements in orange juice with ohmic pasteurization. 


\section{Figure captions}

Fig. 1. Chemical structures of the major xanthophylls of blood orange juice and carotenes from grapefruit juice.

Fig. 2. Kinetic parameters $\left(\mathrm{k}_{70^{\circ} \mathrm{C}}, \mathrm{Ea}\right)$ calculated from experimental points reported in Hadjal, et al., (2013) and Achir, et al., (2015).

Fig. 3. Time-temperature curve during: A) conventional, and B) ohmic heat treatments. The corresponding pasteurization values are presented in: C) for conventional, and D) ohmic heating. Lines in black correspond to $\mathrm{P}$-value $50 \mathrm{~min}$ and lines in grey to $\mathrm{P}-$ value $=150 \mathrm{~min}$. Fig. 4. Experimental (dark grey) and simulated (light grey) carotenoid retentions after conventional heating, with A) P - value $50 \mathrm{~min}, \mathrm{~B}) \mathrm{P}$ - value150 min and ohmic heating, with C) $\mathrm{P}$ - value 50 min and D) $\mathrm{PV}=150$.

Fig. 5. Simulated changes in reduced concentrations of carotenoids $\left(\mathrm{C} / \mathrm{C}_{\mathrm{t}=0}\right)$ cis-violaxanthin, cis-antheraxanthin, lutein, zeaxanthin, and $\beta$-cryptoxanthin during conventional and ohmic heating with $\mathrm{P}$ - value 150 min. Plain lines represent simulated concentrations within 95\% confidence intervals (dotted lines).

Fig. 6. Variations in heating time corresponding to $10 \%$ loss of carotenoids from 40 to $140^{\circ} \mathrm{C}$ calculated with the kinetic data of Fig. 2 (dotted lines) and comparison with equivalent times to reach $\mathrm{P}=100 \mathrm{~min}$ at $70^{\circ} \mathrm{C}$ (plain lines). 


\section{References}

Achir , N., Hadjal , T., Madani, K., Dornier, M., \& Dhuique-Mayer, C. (2015). Carotene reactivity in pink grapefruit juice elucidated from model systems and multi-response modelling. Journal of Agricultural and Food Chemistry, Just Accepted Manuscript (DOI: 10.1021/acs.jafc.5b00509).

Amaya, D. B. (2001). A guide to carotenoid analysis in foods. Washington D.C.: OMNI Research.

Britton, G., Liaanen-Jensen, S., \& Pfander, H. (2004). Carotenoids. Handbook Basel, Switzerland

Butz, P., \& Tauscher, B. (2002). Emerging technologies: chemical aspects. Food Research International, 35(2-3), 279-284.

Chanforan, C. 1., Loonis, M. 1., Mora, N., Caris-Veyrat, C., \& Dufour, C. (2012). The impact of industrial processing on health-beneficial tomato microconstituents. Food Chemistry, 134(4), 1786-1795.

Demirdoven, A. h., \& Baysal, T. (2015). Effects of electrical pre-treatment and alternative heat treatment applications on orange juice production and storage. Food and Bioproducts Processing, 94, 443-452.

Dhuique-Mayer, C., Caris-Veyrat, C., Ollitrault, P., Curk, F., \& Amiot, M. J. (2005). Varietal and Interspecific Influence on Micronutrient Contents in Citrus from the Mediterranean Area. Journal of Agricultural and Food Chemistry, 53, 2140-2145.

Dhuique-Mayer, C., Tbatou, M., Carail, M., Caris-Veyrat, C., Dornier, M., \& Amiot, M. J. (2007). Thermal Degradation of Antioxidant Micronutrients in Citrus Juice: Kinetics and Newly Formed Compounds. Journal of Agricultural and Food Chemistry, 55(10), $4209-4216$. 
Fanciullino, A. L., Dhuique-Mayer, C., Luro, F., Casanova, J., Morillon, R., \& Ollitrault, P. (2006). Carotenoid diversity in cultivated citrus is highly influenced by genetic factors. Journal of Agricultural and Food Chemistry, 54(12), 4397-4406.

FAOstat. (2015).

Giuffrida, D., Dugo, P., Salvo, A., Saitta, M., \& Dugo, G. (2010). Free carotenoid and carotenoid ester composition in native orange juices of different varieties. FRUITS, 65(5), 277-284.

Goullieux, A., \& Pain, J. P. (2014). Ohmic heating. In E. L. Academic Press (Ed.), Emerging technologies for food processing, second edition.

Granado, F., Olmedilla, B., Gil-Martinez, E., \& Blanco, I. (2001). A fast, reliable and lowcost saponification protocol for analysis of carotenoids in vegetables. Journal of Food Composition and Analysis, 14, 479-489.

Hadjal, T., Dhuique-Mayer, C., Madani, K., Dornier, M., \& Achir, N. (2013). Thermal degradation kinetics of xanthophylls from blood orange in model and real food systems. Food Chemistry, 138(4), 2442-2450.

Icier, F., Yildiz, H., \& Baysal, T. (2008). Polyphenoloxidase deactivation kinetics during ohmic heating of grape juice. Journal of Food Engineering, 85(3), 410-417.

Jakób, A., Bryjak, J., Wójtowicz, H., Illeová, V., Annus, J., \& Polakovic, M. (2010). Inactivation kinetics of food enzymes during ohmic heating. Food Chemistry, 123 $369-376$.

Johnson, T. M. (2000). Citrus Juice Production and Fresh Market Extension Technologies. In: FAO.

Khan, I. A., \& Kender, W. J. (2007). Citrus breeding: Introduction and objectives. In C. International (Ed.), (pp. 1-8). Wallingford, Oxfordshire, UK. 
Ladanyia, M. (2008). Citrus Fruit, 1st Edition. Biology, Technology and Evaluation. London, UK.

Laguerre, M., Lecomte, J., \& Villeneuve, P. (2007). Evaluation of the ability of antioxidants to counteract lipid oxidation: Existing methods, new trends and challenges. Progress in Lipid Research, 46(5), 244-282.

Leizerson, S., \& Shimoni, E. (2005a). Effect of Ultrahigh-Temperature Continuous Ohmic Heating Treatment on Fresh Orange Juice. Journal of Agricultural and Food Chemistry, 53(9), 3519-3524.

Leizerson, S., \& Shimoni, E. (2005b). Stability and Sensory Shelf Life of Orange Juice Pasteurized by Continuous Ohmic Heating. Journal of Agricultural and Food Chemistry, 53(10), 4012-4018.

Mercali, G. D., Jaeschke, D. b. P., Tessaro, I. C., \& Marczak, L. D. F. (2013). Degradation kinetics of anthocyanins in acerola pulp: Comparison between ohmic and conventional heat treatment. Food Chemistry, 136(2), 853-857.

Mercali, G. D., Schwartz, S., Marczak, L. D. F., Tessaro, I. C., \& Sastry, S. (2014). Ascorbic acid degradation and color changes in acerola pulp during ohmic heating: Effect of electric field frequency. Journal of Food Engineering, 123(0), 1-7.

Pataro, G., Donsi, G., \& Ferrari, G. (2011). Aseptic processing of apricots in syrup by means of a continuous pilot scale ohmic unit. LWT - Food Science and Technology, 44(6), $1546-1554$.

Penicaud, C., Achir, N., Dhuique-Mayer, C., Dornier, M., \& Bohuon, P. (2011). Degradation of $\beta$-carotene during fruits and vegetables processing or storage: reaction mechanisms and kinetics aspects. FRUITS, 66(6), 417-440. 
Roux, S., Courel, M., Picart-Palmade, L., \& Pain, J.-P. (2010). Design of an ohmic reactor to study the kinetics of thermal reactions in liquid products. Journal of Food Engineering, 98(4), 398-407.

Sakr, M., \& Liu, S. (2014). A comprehensive review on applications of ohmic heating (OH). Renewable and Sustainable Energy Reviews, 39(0), 262-269.

Sarkis, J. 1. R., Jaeschke, D. b. P., Tessaro, I. C., \& Marczak, L. D. F. (2013). Effects of ohmic and conventional heating on anthocyanin degradation during the $\hat{A}$ processing of blueberry pulp. LWT - Food Science and Technology, 51(1), 79-85.

Silva, F. V. M., \& Gibbs, P. (2004). Target Selection in Designing Pasteurization Processes for Shelf-Stable High-Acid Fruit Products. Critical Reviews in Food Science and Nutrition, 44, 353-360.

Somavat, R., Mohamed, H. M. H., \& Sastry, S. K. (2013). Inactivation kinetics of Bacillus coagulans spores under ohmic and conventional heating. LWT - Food Science and Technology, 54(1), 194-198.

Tucker, G., \& Featherstone, S. (2011). Essentials of Thermal Processing. . Chichester.

Vikram, V. B., Ramesh, M. N., \& Prapulla, S. G. (2005). Thermal degradation kinetics of nutrients in orange juice heated by electromagnetic and conventional methods. Journal of Food Engineering, 69(1), 31-40.

Xu, J., Tao, N., Liu, Q., \& Deng, X. (2006). Presence of diverse ratios of lycopene/ $\beta$-carotene in five pink or red-fleshed citrus cultivars. Scientia Horticulturae, 108(2), 181-184. 


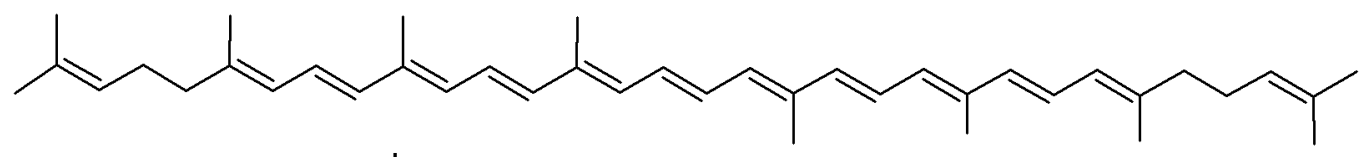

lycopene<smiles>CC1=C(/C=C/C(C)=C/C=C/C(C)=C/C=C/C=C(C)/C=C/C=C(C)/C=C/C2=C(C)CCCC2(C)C)C(C)(C)CCC1</smiles><smiles>CC1=C(/C=C/C(C)=C/C=C/C(C)=C/C=C/C=C(C)/C=C/C=C(C)/C=C/C2=C(C)CC(O)CC2(C)C)C(C)(C)CCC1</smiles><smiles>CC1=C(/C=C/C(C)=C/C=C/C(C)=C/C=C/C=C(C)/C=C/C=C(C)/C=C/C2=C(C)CC(O)CC2(C)C)C(C)(C)CC(O)C1</smiles><smiles>CC1=CC(O)CC(C)(C)C1/C=C/C(C)=C/C=C/C(C)=C/C=C/C=C(C)/C=C/C=C(C)/C=C/C1=C(C)CC(O)CC1(C)C</smiles><smiles>CC1=C(/C=C/C(C)=C/C=C/C(C)=C/C=C/C=C(C)/C=C/C=C(C)/C=C/[C@]2(C)C(C)CC(O)CC2(C)C)C(C)(C)CC(O)C1</smiles><smiles>CC(/C=C/C=C(C)/C=C/[C@@]1(O)C(C)CC(O)CC1(C)C)=C\C=C\C=C(C)\C=C\C=C(C)\C=C\[C@]1(O)C(C)CC(O)CC1(C)C</smiles>

Figure 1 


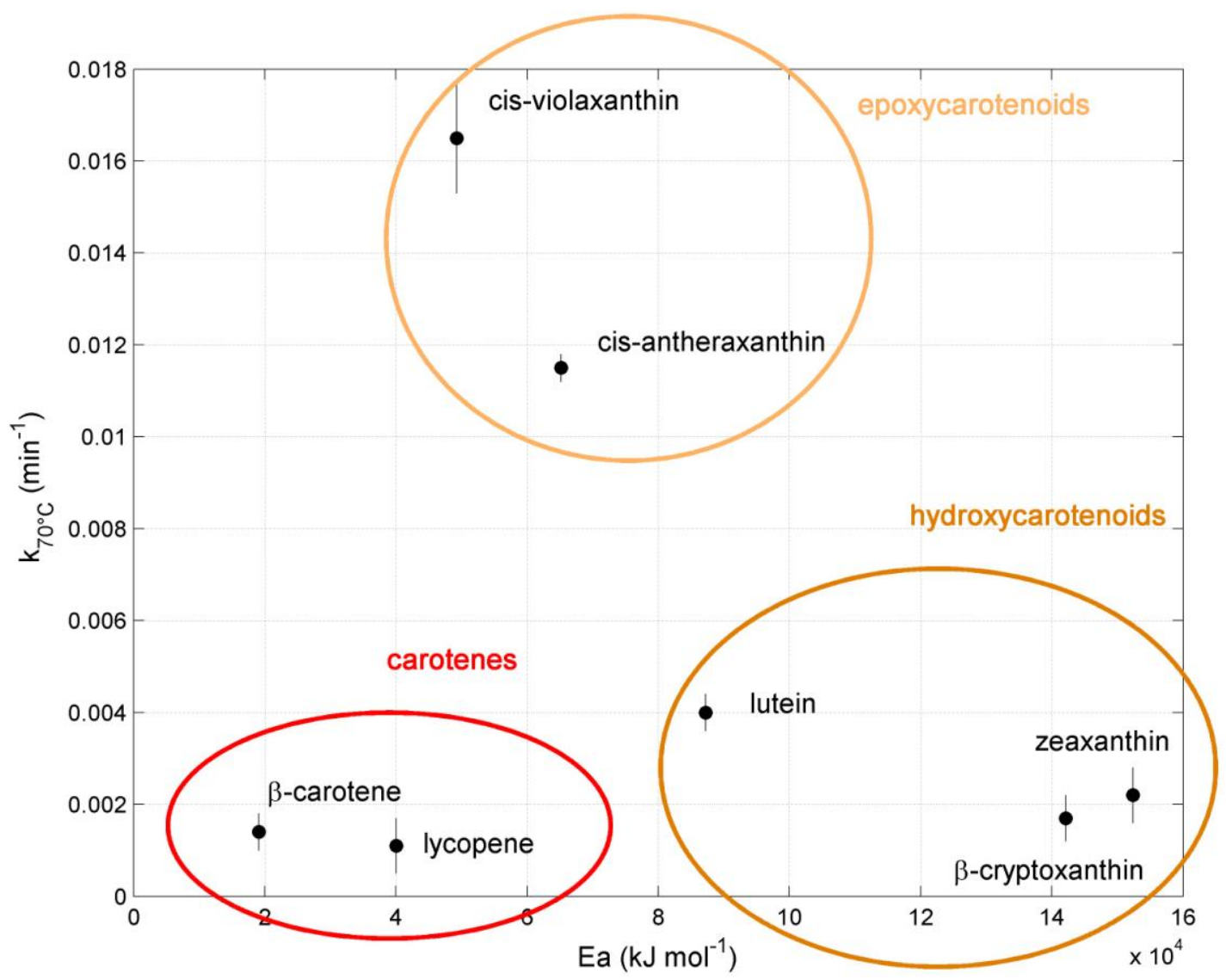

Figure 2 

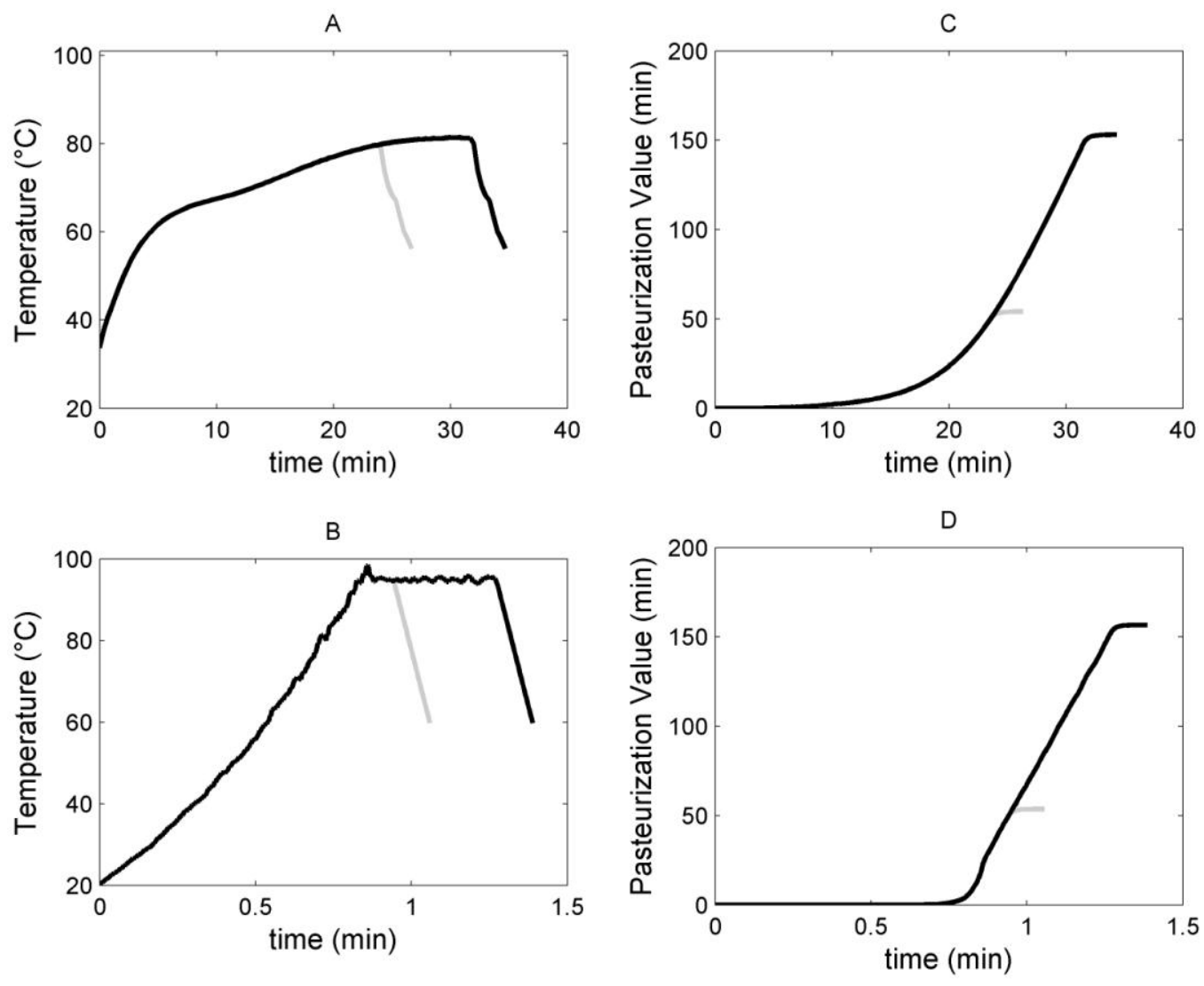

Figure 3 


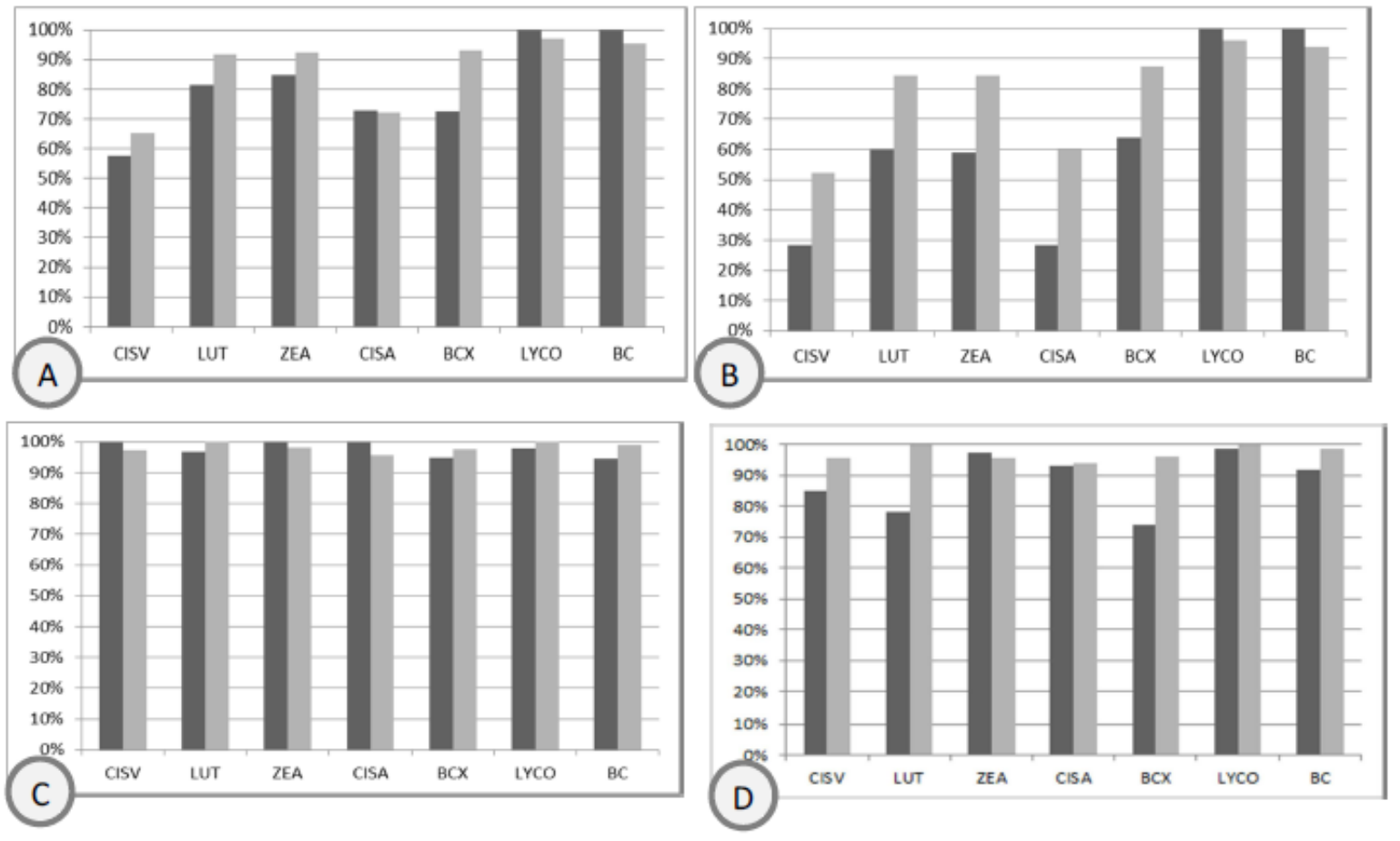

Figure 4 

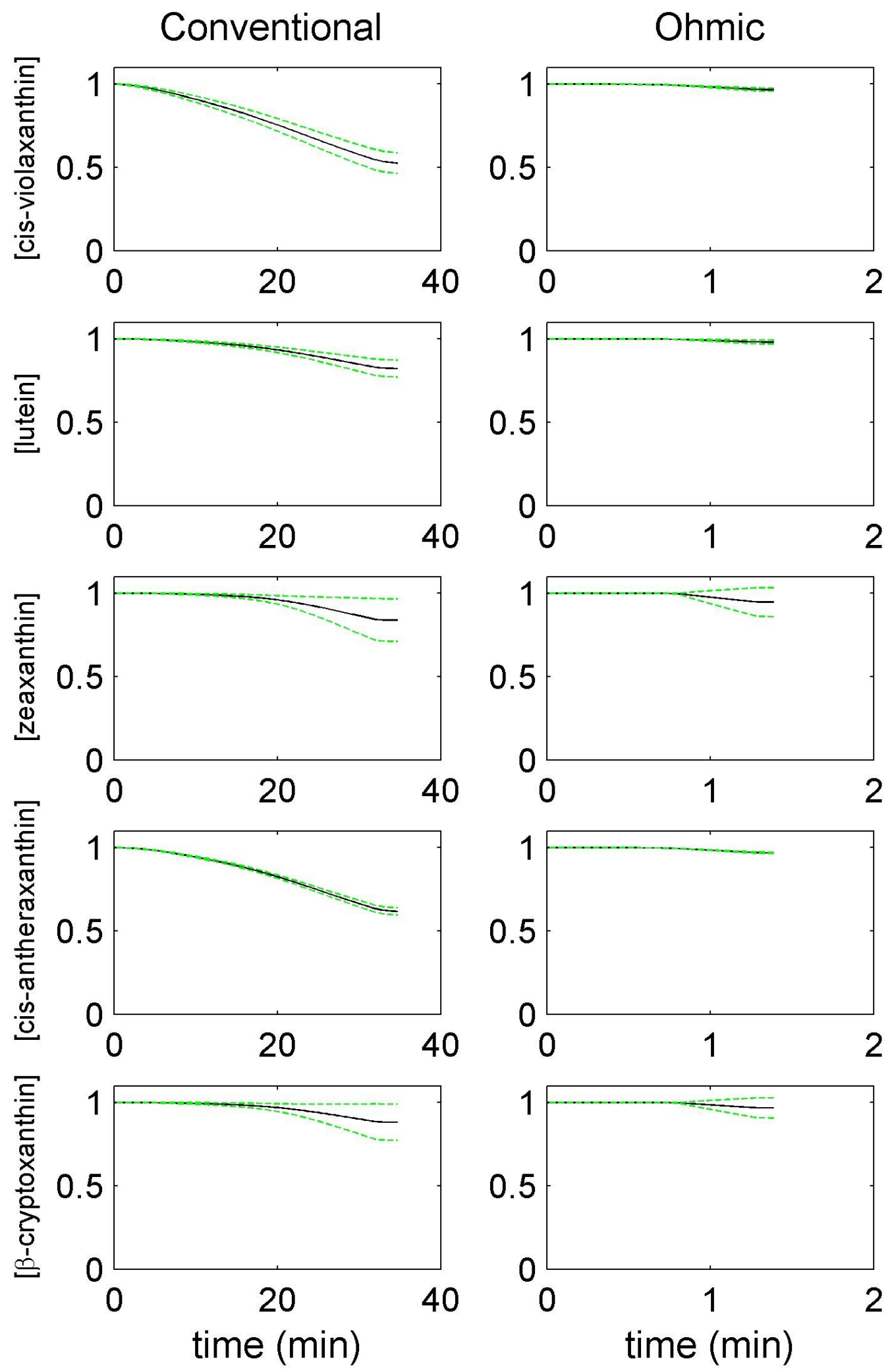

Figure 5 


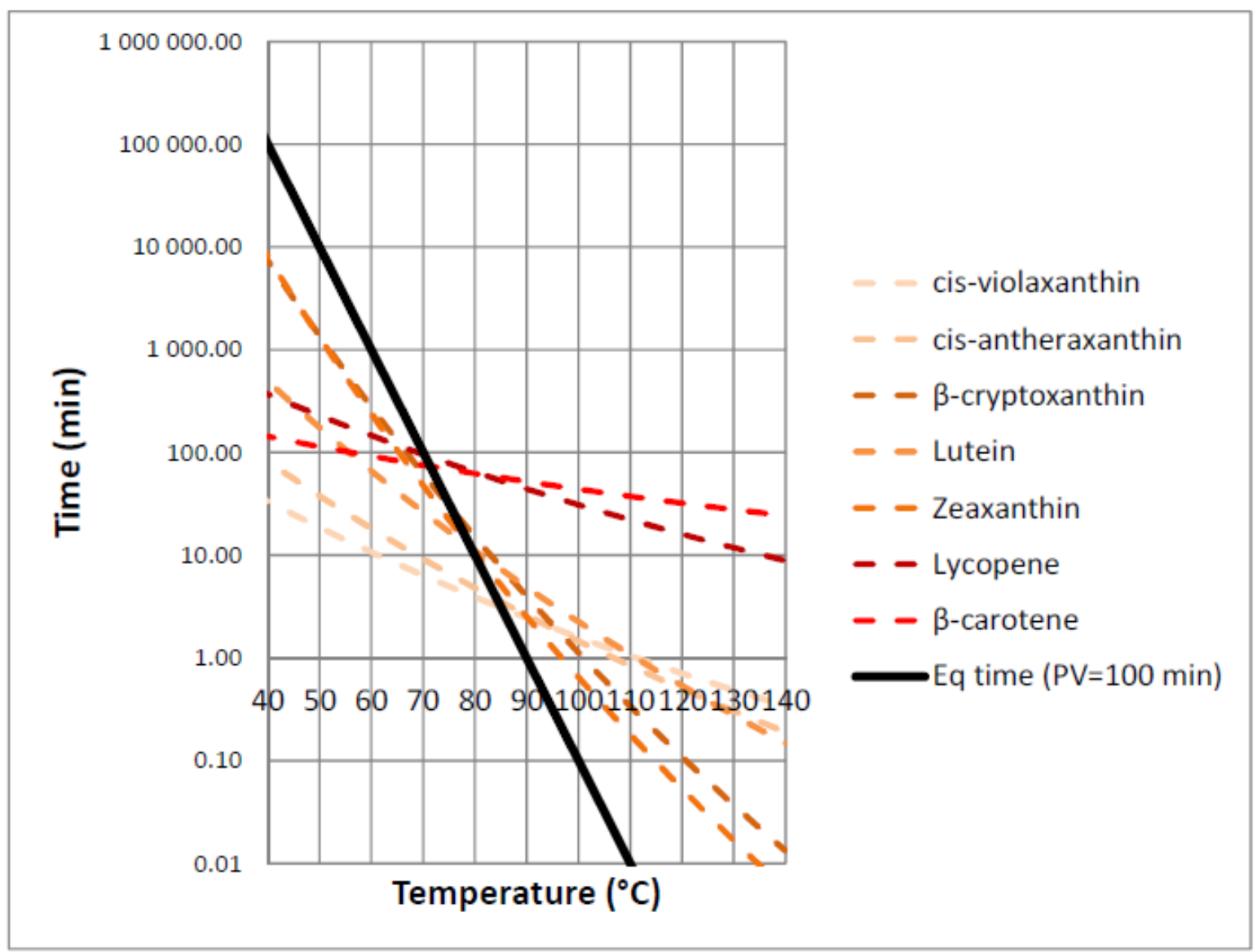

Figure 6 
Industrial relevance: Citrus are the top fruit crops in terms of world trade. This craze for them -particularly orange and grapefruit- is notably due to their high content in organoleptic and nutritional compounds of interest and among them carotenoids. About $50 \%$ of the Citrus production is processed in juice. From the growing variety of products, minimal processed juices now have a significant market share. This work assessed for the first time the effect of ohmic heating, a thermal method for stabilizing juices while minimizing the impact on the juice quality, on the carotenoid profiles of blood orange and grapefruit juice. Pasteurization with ohmic heating was proven to be a very good alternative for protecting carotenoids and especially xanthophylls compared to conventional heating. These results will help in designing ohmic heating process parameters for optimizing the overall quality of carotenoidrich fruit juices. 


\section{Highlights}

Ohmic heating pasteurization treatment tested on grapefruit and blood orange juices Carotenoid profile retention during ohmic heating compared with conventional heating Citrus juices xanthophylls are markedly more preserved by ohmic heating 